\title{
Comparative TPR and TPD Studies of Cu and Ca Promotion on Fe-Zn- and Fe-Zn-Zr-Based Fischer-Tropsch Catalysts
}

\author{
Olusola O. James ${ }^{1,2 *}$, Biswajit Chowdhury ${ }^{2}$ and Sudip Maity ${ }^{1}$ \\ ' Liquid Fuels Section, Central Institute of Mining and Fuel Research (Digwadih Campus), PO FRI 828108, Dhanbad - India \\ ${ }^{2}$ Applied Chemistry Department, Indian School of Mines, Dhanbad - India \\ e-mail: jamesoladele2003@yahoo.com - biswajit_chem2003@yahoo.com - sudip_maity@yahoo.com \\ * Corresponding author
}

\begin{abstract}
Résumé - Études comparatives par TPR et TPD de la promotion par Cu et Ca de I'activité de catalyseurs Fischer-Tropsch Fe-Zn et $\mathbf{F e}-\mathbf{Z n}-\mathbf{Z r}$ - Cette étude montre l'effet promoteur du zirconium sur les catalyseurs à base de $\mathrm{Fe}-\mathrm{Zn}$ pour stimuler les sites actifs des catalyseurs Fischer-Tropsch (FT). Les sites actifs des catalyseurs sont également favorisés par du cuivre et du calcium et ils sont examinés en utilisant un programme de réduction en température (TPR, Temperature-Programmed Reduction) sous $\mathrm{H}_{2}$ et $\mathrm{CO}$ et un programme de désorption en température (TPD, Temperature-Programmed Desorption) sous $\mathrm{NH}_{3}$ et de $\mathrm{CO}_{2}$. Les résultats sont présentés sous forme d'une étude comparative entre les catalyseurs $\mathrm{Fe}-\mathrm{Zn}$ et ceux Fe-Zn$\mathrm{Zr}$. Les résultats montrent que l'addition de $\mathrm{Zr}$ au catalyseur Fe-Zn augmente la disponibilite et la dispersion des précurseurs des sites actifs et que la promotion par du cuivre ou du calcium, indépendamment et en synergie, améliore la réduction des catalyseurs de Fe-Zn-Zr. La présence de calcium favorise la carburation alors que celle du cuivre l'inhibe. L'effet du calcium et du cuivre sur l'acidité/basicité de la surface est gouvemé par la nature des interactions entre les phases du catalyseurs. L'ampleur de la réduction reflète la disponibilité et la dispersion des précurseurs de la phase active tandis que l'étendue de la carburation influera sur la sélectivité des catalyseurs.
\end{abstract}

\begin{abstract}
Comparative TPR and TPD Studies of Cu and Ca Promotion on Fe-Zn-and Fe-Zn-ZrBased Fischer-Tropsch Catalysts - The present study demonstrates the effect of zirconium promotion on Fe-Zn-based catalysts to boost the active sites of Fischer-Tropsch (FT) catalysts. The catalysts are also promoted by $\mathrm{Cu}$ and $\mathrm{Ca}$ and the active sites are examined using Temperature-Programmed Reduction (TPR) with $\mathrm{H}_{2}$ and $\mathrm{CO}$ and Temperature-Programmed Desorption (TPD) with $\mathrm{NH}_{3}$ and $\mathrm{CO}_{2}$. The results are presented as a comparative study between $\mathrm{Fe}-\mathrm{Zn}$ and $\mathrm{Fe}-\mathrm{Zn}$-Zr-based catalysts. The results show that addition of $\mathrm{Zr}$ to Fe-Zn catalysts increases the availability and dispersion of the precursor to the active sites and promotion with $\mathrm{Cu}$ and $\mathrm{Ca}$ independently and synergistically enhances reduction of $\mathrm{Fe}-\mathrm{Zn}$-Zr-based catalysts. The presence of $\mathrm{Ca}$ promotes carburisation, while $\mathrm{Cu}$ inhibits carburisation. The impact of the $\mathrm{Ca}$ and $\mathrm{Cu}$ on the surface acidity/basicity is governed by the nature of the interaction between the phases in the catalysts. The extent of reduction reflects the availability and dispersion of the precursor to the active phase, while the extent of carburisation will impact on the selectivity of the catalysts.
\end{abstract}




\section{INTRODUCTION}

Presently, global energy needs are being met largely by fossil fuels. In particular, due to their high energy density, liquid fuels occupy the central place in the present energy system. Although for socioeconomic, political and environmental reasons, there are motivations for a paradigm shift from fossil fuels to a hydrogen- and renewable energy-based economy, liquid fuels will still play an important role in the future energy system. Petroleum is the primary resource of liquid fuels; however, there is increasing awareness of the diminishing world crude oil reserves $[1,2]$. This has brought about a renaissance of discussions on FT technology in recent times [3-5]. FT technology provides an alternative route to liquid fuels from many carbonaceous resources. Moreover, discovery of more gas resources and regulations to discourage flaring of associated gases in oil wells has been a boost to the current wave of GTL projects [5]. GTL is typically based on the LTFT operation mode.

Catalyst design is a critical aspect of FT technology. Commercial LTFT catalysts are based on iron and cobalt [6]. Neither of the two metals have an absolute advantage over the other. Cobalt catalysts generally have higher intrinsic activity, exhibit lower Water Gas Shift (WGS) activity, and more resistance to moisture and coking-induced deactivation than iron-based catalysts. Hence, there seems to be a preference for cobalt-based catalysts for GTL [7]. However, iron-based catalysts are more resistant to sulphur poisoning, exhibit lower methane selectivity and their product selectivities are less susceptible to variations in process conditions. Moreover, a typical iron-based FT catalyst is about 25 times less expensive than a cobalt-based FT catalyst [8]. In addition, ease of refining of syncrudes to a specified diesel fuel indicates that iron-based LTFT syncrude poses less refining challenges compared with cobalt-based LTFT [9]. Thus, cobalt-based catalysts do not appear to have an absolute advantage over iron-based catalysts. In fact, with rational catalyst design, some of the previous advantages of cobalt over iron as a FT catalyst may cease to exist, while iron retains the lower cost edge that can lead to an enhanced process and FT process economy, and hence the motivation for this study.

The main areas of improvement needed for iron to compete head-to-head with cobalt for LTFT are: lowering of WGS activity $/ \mathrm{CO}_{2}$ selectivity, increased activity and improved resistance to coking and deactivation by moisture. In a recent review report, the present authors showed that the key catalytic features that govern the performance of a FT catalyst are: hydrogenation activity, surface acidity and basicity. Hydrogenation activity determines the hydrocarbon formation rate, while surface acidity/basicity influences the product selectivity of the catalyst. State-of-the-art commercial iron-based $\left(\mathrm{Fe}-\mathrm{SiO}_{2}\right)$ catalysts are WGS active, which accounts for their higher $\mathrm{CO}_{2}$ selectivity in LTFT compared with cobalt-based catalysts. Attention has been drawn to the $\mathrm{ZnFe}_{2} \mathrm{O}_{4}$ spinel phase and its effect on $\mathrm{CO}_{2}$ selectivity in $\mathrm{Fe}-\mathrm{Zn}$-based catalysts [10]. Several reports examine $\mathrm{CO}$ [11] and $\mathrm{CO}_{2}$ [12-14] hydrogenation over $\mathrm{Fe}-\mathrm{Zn}$-based catalysts and the present authors have arrived at an optimum $\mathrm{Zn} / \mathrm{Fe}$ ratio of 0.25 to achieve low $\mathrm{CO}_{2}$ selectivity with a minimised compromise of the FTS active site precursor. Although copper and potassium are benchmark promoters in commercial iron-based FT catalysts, potassium has been found to enhance WGS activity in Fe-Zn-based catalysts. To circumvent the undesired boost of WGS activity, we have use calcium in place of potassium. LTFT tests of the unpromoted, $\mathrm{Cu}$ - and $\mathrm{Ca}$-promoted catalysts show very low $\mathrm{CO}_{2}$ selectivity. The $\mathrm{Cu}$-promoted $\mathrm{Fe}-\mathrm{Zn}$ catalyst has a lower surface area, higher hydrocarbon formation rate and virtually zero wax selectivity. The unpromoted Fe-Zn catalyst displays higher wax selectivity than the Ca-promoted catalyst.

It has been argued that the lower FT synthesis rate on Fe-based catalysts compared with cobalt-based catalysts is closely related to lower dispersion of the active components in iron catalysts. Li et al. [15] demonstrated that, in addition to the lower reaction temperature typical of LTFT, iron catalysts of comparable hydrocarbon synthesis rates to their cobalt-based counterparts can be achieved by design strategies that lead to high dispersion of the active component. They have shown that $\mathrm{Fe}-\mathrm{Zn}-\mathrm{K}-\mathrm{Cu}$ oxide precursors prepared using a solvent replacement method have higher hydrocarbon synthesis rates (per catalyst mass or volume) compared with those on Co-based catalysts under identical reaction conditions. It has been shown that an increase in dispersion of active sites and higher TOF can be achieved by addition of another promoter (such as $\mathrm{Zr}$, Mn or $\mathrm{Cr}$ ) to the $\mathrm{Fe}$ oxide precursor $[16,17]$. Achieving increased dispersion of active sites by introduction and co-precipitation of an additional promoter is more adaptable for largescale operation than the solvent replacement method.

Building on the low $\mathrm{CO}_{2}$ selectivity of the $\mathrm{Fe}-\mathrm{Zn}$-based catalysts, we seek a way to bring their activities on par with that of a typical cobalt-based catalyst. Thus, in this contribution, we explored the introduction of $\mathrm{Zr}$ promotion as an easily scalable method to enhance the activity of the Fe- Zn catalysts. We examined the effect of addition of $\mathrm{Zr}$ on the FT relevant active sites in the catalysts. Although dispersion of active sites may correlate with textural properties, the results we obtained in the LTFT tests of the 
Fe-Zn catalysts suggest their performance is governed by interplay of their active sites rather than their textural properties. The $\mathrm{Fe}_{2} \mathrm{O}_{3} \rightarrow \mathrm{Fe}_{3} \mathrm{O}_{4}$ reduction peak in the $\mathrm{H}_{2}$-TPR profiles of the catalysts is a measure of the hydrogenation activity of the catalysts. Low peak temperature indicates high hydrogenation tendency. The area under the peak vis-à-vis amount of hydrogen consumed gives a measure of the density of the FTS active precursors. The extent of CO carburisation provides a measure of wax formation, coking tendency and resistance to moisture deactivation. Surface acidity/basicity has an influence on the product distributions of the catalysts. Hence, we focused our study on these characterisation techniques since they provide a direct measure of the active sites.

\section{EXPERIMENTAL}

\subsection{Catalyst Preparation}

The catalysts are prepared by the co-precipitation technique. $\mathrm{Na}_{2} \mathrm{CO}_{3}(2.5 \mathrm{M})$ solution is added dropwise to a solution $(0.5 \mathrm{M})$ containing the nitrate salts of the metals in the desired ratio to $\mathrm{pH}=8.5 \pm 0.5$ while the temperature is maintained between $70-80^{\circ} \mathrm{C}$ under mixing with the aid of a motor stirrer. The resulting precipitates are washed with double-distilled water until the filtrates are nitrate-free. The precipitates are dried overnight and calcined at $400^{\circ} \mathrm{C}$ for 4 hours. The atomic ratio of the constituent metal in the catalysts used in this study is presented in Table 1 .

\subsection{Temperature-Programmed Reduction (TPR)}

TPR and TPD profiles of the catalysts are obtained with ChemiSorb 2720 (Micrometrics, USA) equipped with a TCD detector. The $\mathrm{H}_{2}$-TPR profiles are obtained by reducing the catalyst samples by a gas mixture of $10 \% \mathrm{H}_{2}$ in Ar with a flow rate of $20 \mathrm{~mL} / \mathrm{min}$, and the temperature is increased from ambient to $800^{\circ} \mathrm{C}$ at a rate of $10^{\circ} \mathrm{C} / \mathrm{min}$. The CO-TPR are obtained by heating the catalyst samples by a gas mixture of $5.2 \% \mathrm{CO}$ in $\mathrm{He}$ with a flow rate of $20 \mathrm{~mL} / \mathrm{min}$ and the temperature is increased from ambient to $800^{\circ} \mathrm{C}$ at a rate of $10^{\circ} \mathrm{C} / \mathrm{min}$. Hydrogen consumption in the TPR peak area is evaluated by the peak area of the $\mathrm{CuO}$ TPR calibration.

\subsection{Temperature-Programmed Desorption (TPD)}

The TPD is carried out by first reducing a catalyst with $\mathrm{H}_{2}$ at $400^{\circ} \mathrm{C}$ for $8 \mathrm{~h}$. The gas flow is then switched to $\mathrm{He}$ and the temperature is raised to $450^{\circ} \mathrm{C}$ at a rate of $10^{\circ} \mathrm{C} / \mathrm{min}$ and kept at $450^{\circ} \mathrm{C}$ for $30 \mathrm{~min}$ and then cooled to ambient temperature to eliminate adsorbed $\mathrm{H}_{2}$ from the catalyst surface. $\mathrm{NH}_{3}$ uptake on the catalyst surface takes place when the gas flow is changed to $4 \% \mathrm{NH}_{3}$ in $\mathrm{He}$. The $\mathrm{NH}_{3}$-TPD profile is obtained by a temperatureprogrammed desorption under $\mathrm{He}$ with a flow rate of $20 \mathrm{~mL} / \mathrm{min}$ from ambient temperature to $1000^{\circ} \mathrm{C}$ at a rate of $10^{\circ} \mathrm{C} / \mathrm{min} . \mathrm{CO}_{2}$-TPD is obtained by the same procedure using 5.2\% $\mathrm{CO}_{2}$ in $\mathrm{He}$ for the $\mathrm{CO}_{2}$ uptake. The amounts of $\mathrm{NH}_{3}$ and $\mathrm{CO}_{2}$ desorbed in the TPD peak area are evaluated by comparing with a calibration graph obtained by measured pulses of $\mathrm{NH}_{3}$ and $\mathrm{CO}_{2}$ in a flow of $\mathrm{He}$.

\section{RESULTS AND DISCUSSION}

\subsection{Reduction Behaviour}

Fe-Zn oxide precursors are transformed into $\alpha-\mathrm{Fe}_{2} \mathrm{O}_{3}$ and $\mathrm{ZnFe}_{2} \mathrm{O}_{4}$ phases after calcination at $400^{\circ} \mathrm{C}$. The $\alpha-\mathrm{Fe}_{2} \mathrm{O}_{3}$ phase is recognised to be the precursor to the active sites, carbide phases, during the activation/ carburisation step prior to the FT reaction. Figure 1 shows the H-TPR profiles of $\mathrm{Fe}-\mathrm{Zn}$ oxide at the $\mathrm{Zn} / \mathrm{Fe}$ ratios $0,0.1,0.2$ and 0.25 . The profile of the zinc-free oxide displays two features, a narrow peak

TABLE 1

Atomic ratios of the constituent metal of the catalysts

\begin{tabular}{c|c|c|c}
\hline \multicolumn{2}{c|}{ Fe-Zn Series } & \multicolumn{2}{c}{ Fe-Zn-Zr Series } \\
\hline Catalyst & Atomic ratio & Catalyst & Atomic ratio \\
\hline Fe-Zn & $100: 25$ & Fe-Zn-Zr & $100: 25: 2.5$ \\
\hline Fe-Zn-Cu & $100: 25: 2$ & Fe-Zn-Zr-Cu & $100: 25: 2.5: 2$ \\
\hline Fe-Zn-Ca & $100: 25: 1.5$ & Fe-Zn-Zr-Ca & $100: 25: 2.5: 1.5$ \\
\hline Fe-Zn-Cu-Ca & $100: 25: 2: 1.5$ & Fe-Zn-Zr-Cu-Ca & $100: 25: 2.5: 2: 1.5$ \\
\hline
\end{tabular}


at $370^{\circ} \mathrm{C}$ and broad multiple peaks in the range of temperatures $400-900^{\circ} \mathrm{C}$. The narrow peaks are assigned to the $\mathrm{Fe}_{2} \mathrm{O}_{3} \rightarrow \mathrm{Fe}_{3} \mathrm{O}_{4}$ transition, while the broad multiple peaks are assigned to $\mathrm{Fe}_{3} \mathrm{O}_{4} \rightarrow \mathrm{FeO} \rightarrow \mathrm{Fe}$ transitions. The H-TPR profiles of $\mathrm{Fe}-\mathrm{Zn}$ oxides display similar features to the zinc-free Fe oxide; hence, similar assignments are made for them. The temperature of the peak assigned to the $\mathrm{Fe}_{2} \mathrm{O}_{3} \rightarrow \mathrm{Fe}_{3} \mathrm{O}_{4}$ transition decreases with increasing zinc content. However, the areas under the peaks decrease with increasing zinc content. Part of the iron is used up at the stoichiometric ratio of $2: 1(\mathrm{Zn}: \mathrm{Fe})$ in forming the $\mathrm{ZnFe}_{2} \mathrm{O}_{4}$ phase. Analyses of the TPR profiles confirm the stoichiometric ratio. The calculated percentage of hydrogen consumption under these peaks corresponds with the experimental value determined by the proportion of the peak to the total hydrogen consumption in each case (Fig. 2). At a $\mathrm{Zn} / \mathrm{Fe}$ ratio of 0.25 , the proportions of the $\alpha-\mathrm{Fe}_{2} \mathrm{O}_{3}$

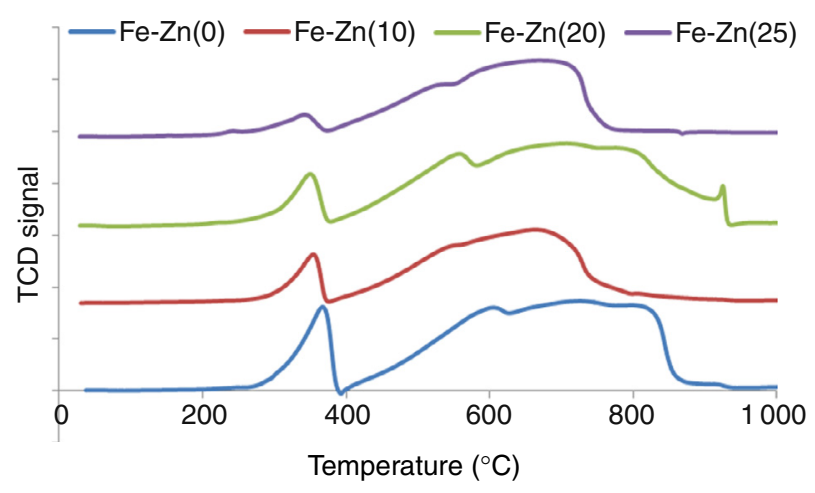

Figure 1

$\mathrm{H}$-TPR of Fe- $\mathrm{Zn}$ oxide at the $\mathrm{Zn} / \mathrm{Fe}$ ratios $0,0.1,0.2$ and 0.25 .

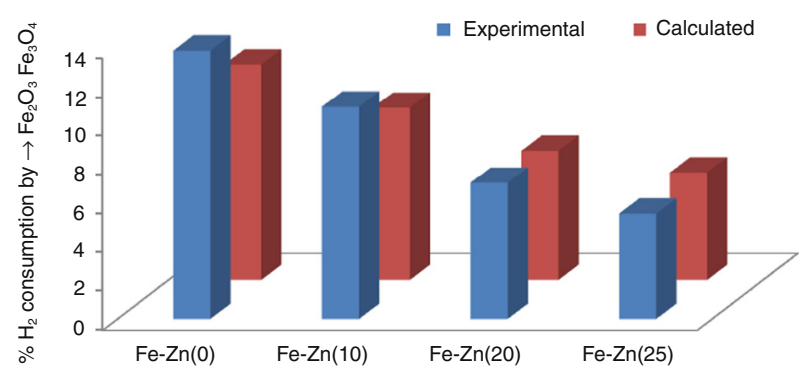

Figure 2

Comparison of calculated percent hydrogen consumption to experimental values of $\mathrm{Fe}-\mathrm{Zn}$ oxide at the $\mathrm{Zn} / \mathrm{Fe}$ ratios $0,0.1,0.2$ and 0.25 . and $\mathrm{ZnFe}_{2} \mathrm{O}_{4}$ phases are expected stoichiometrically. The effects of the promoters are examined on the $\mathrm{Fe}-\mathrm{Zn}(\mathrm{Zn} / \mathrm{Fe}=0.25)$ catalysts.

$\mathrm{ZnFe}_{2} \mathrm{O}_{4}$, being less reducible than $\alpha-\mathrm{Fe}_{2} \mathrm{O}_{3}$, is regarded as a textural promoter that increases the surface area and dispersion and prevents the sintering of the $\alpha-\mathrm{Fe}_{2} \mathrm{O}_{3}$ phase [12]. However, the $\mathrm{ZnFe}_{2} \mathrm{O}_{4}$ phase has been implicated as an active component which is capable of converting $\mathrm{CO}_{2}$ into methanol [12-14]. It can therefore be suggested that the $\mathrm{ZnFe}_{2} \mathrm{O}_{4}$ phase does not only act as a structural promoter, it also plays a key role in the lower $\mathrm{CO}_{2}$ selectivity by in situ recycling of $\mathrm{CO}_{2}$ generated by WGS and oxygen removal via a direct $\mathrm{CO}$ dissociation mechanism [18]. Phases due to the promoter are virtually absent in X-ray diffractograms of the catalysts. Moreover, the $\alpha-\mathrm{Fe}_{2} \mathrm{O}_{3}$ phase is the main active phase that is directly connected to hydrocarbon formation; hence, we examine the presence of the promoters which affect the reduction and carburisation of the $\alpha-\mathrm{Fe}_{2} \mathrm{O}_{3}$ phase in the catalysts.

The readily reducible phases in the catalysts are $\mathrm{CuO}$ and $\alpha-\mathrm{Fe}_{2} \mathrm{O}_{3}$. The promotion effect of $\mathrm{Cu}$ on the reduction of $\alpha-\mathrm{Fe}_{2} \mathrm{O}_{3}$ through the hydrogen spillover effect is well documented. Figure 3 shows the $\mathrm{H}_{2}$-TPR profiles of the catalysts grouped into $\mathrm{Fe}-\mathrm{Zn}$ series and $\mathrm{Fe}-\mathrm{Zn}-\mathrm{Zr}$ series. The partition line is used to demarcate the peaks assigned to the $\mathrm{Fe}_{2} \mathrm{O}_{3} \rightarrow \mathrm{Fe}_{3} \mathrm{O}_{4}$ transition. In the two groups, it can be observed that the presence of $\mathrm{Ca}$ has no influence on the reducibility of the $\alpha-\mathrm{Fe}_{2} \mathrm{O}_{3}$ phase. However, $\mathrm{Cu}$ promotion enhances the conversion of $\mathrm{Fe}_{2} \mathrm{O}_{3}$ into $\mathrm{Fe}_{3} \mathrm{O}_{4}$. In the $\mathrm{Fe}-\mathrm{Zn}$ series, the peak temperature of the $\mathrm{Fe}_{2} \mathrm{O}_{3} \rightarrow \mathrm{Fe}_{3} \mathrm{O}_{4}$ transition is lowered by $125^{\circ} \mathrm{C}$. Co-promotion of $\mathrm{Fe}-\mathrm{Zn}$ with $\mathrm{Cu}$ and $\mathrm{Ca}$ further decreases the $\mathrm{Fe}_{2} \mathrm{O}_{3} \rightarrow \mathrm{Fe}_{3} \mathrm{O}_{4}$ reduction temperature by about $40^{\circ} \mathrm{C}$. A similar trend of reduction of peak temperature is observed in the $\mathrm{Fe}-\mathrm{Zn}-\mathrm{Zr}$ series. It is noteworthy that the peak temperature of the $\mathrm{Fe}_{2} \mathrm{O}_{3} \rightarrow \mathrm{Fe}_{3} \mathrm{O}_{4}$

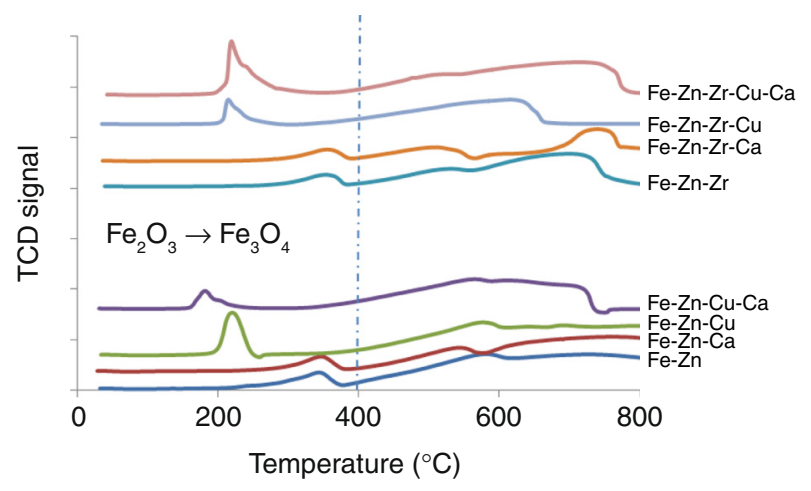

Figure 3

$\mathrm{H}_{2}$-TPR profiles of the catalysts. 
transition in $\mathrm{Fe}-\mathrm{Zn}-\mathrm{Zr}-\mathrm{Cu}$ is lower than that of $\mathrm{Fe}-\mathrm{Zn}-\mathrm{Cu}$. It appears that $\mathrm{Cu}-\mathrm{CaOx}$ and $\mathrm{Cu}-\mathrm{ZrO}_{2}$ couples in the catalyst display higher efficiency of $\mathrm{H}_{2}$ cleavage and the hydrogen spillover effect towards the conversion of $\mathrm{Fe}_{2} \mathrm{O}_{3}$ into $\mathrm{Fe}_{3} \mathrm{O}_{4}$ compared with $\mathrm{Cu}$ alone in the catalysts. This suggests that a complementary Lewis basic site is beneficial to a transition metal site (Lewis acidic) for efficient $\mathrm{H}_{2}$ activation [19].

It is important to draw attention to the right hand side of the partition in Figure 3. There are two reduction peaks in this region of the TPR profiles. In the Fe- $\mathrm{Zn}$ series, distinction of the peaks appears more apparent for the Cacontaining catalysts but it becomes less noticeable in the $\mathrm{Cu}$-containing catalysts. The profiles of the Fe- Zn- Zr reveal a similar pattern but here, distinction of the peaks is more noticeable. The presence of $\mathrm{Zr}$ and $\mathrm{Ca}$ delineates the transition under the peaks and this delineation of the peaks in this region may be attributed to segregation of the phases under the peaks. The segregation appears stronger with $\mathrm{Zr}$ than with $\mathrm{Ca}$ but it is additive in the presence of $\mathrm{Zr}$ and $\mathrm{Ca}$. However, the peak differentiation effect becomes blurred in the $\mathrm{Cu}$-containing catalysts.

A comparison of hydrogen consumptions for the $\mathrm{Fe}_{2} \mathrm{O}_{3} \rightarrow \mathrm{Fe}_{3} \mathrm{O}_{4}$ transitions for the catalysts as measured by the area under the peaks is shown in Figure 4. The figure shows that hydrogen consumptions for the $\mathrm{Fe}_{2} \mathrm{O}_{3} \rightarrow \mathrm{Fe}_{3} \mathrm{O}_{4}$ transitions in the $\mathrm{Fe}-\mathrm{Zn}$ series catalysts are very similar. This suggests that the amount of the $\mathrm{Fe}_{2} \mathrm{O}_{3}$ phase in the $\mathrm{Fe}-\mathrm{Zn}$ series catalysts is broadly the same. However, hydrogen consumptions for the $\mathrm{Fe}_{2} \mathrm{O}_{3} \rightarrow \mathrm{Fe}_{3} \mathrm{O}_{4}$ transitions in the Fe- $\mathrm{Zn}$ - Zr catalyst series present an interesting trend. Beginning from Fe-Zn-Zr, slightly higher hydrogen consumption is observed compared with those of the Fe- $\mathrm{Zn}$ series. The most probable reaction at this peak temperature is $\mathrm{Fe}_{2} \mathrm{O}_{3} \rightarrow \mathrm{Fe}_{3} \mathrm{O}_{4}$, which suggests that the presence of $\mathrm{ZrO}_{2}$ in the Fe- $\mathrm{Zn}$ oxide precursor decreases the proportion of $\mathrm{Fe}$ that is used up in forming the $\mathrm{ZnFe}_{2} \mathrm{O}_{4}$ phases. It implies that $\mathrm{Zr}$ promotion of $\mathrm{Fe}-\mathrm{Zn}$ leads to an increased proportion of active site precursors, the $\mathrm{Fe}_{2} \mathrm{O}_{3}$ phase, while also serving as a textural component for increased dispersion of the $\alpha-\mathrm{Fe}_{2} \mathrm{O}_{3}$ or $\mathrm{ZnFe}_{2} \mathrm{O}_{4}$ phases. This promotion effect is enhanced when $\mathrm{Ca}$ is added to $\mathrm{Fe}-\mathrm{Zn}-\mathrm{Zr}$. Interestingly, $\mathrm{Fe}-\mathrm{Zn}-\mathrm{Zr}-\mathrm{Cu}$ displays greater hydrogen consumption than $\mathrm{Fe}-\mathrm{Zn}-\mathrm{Zr}-\mathrm{Ca}$. Here, $\mathrm{CuO}$ is also a beneficiary of the dispersion effect of $\mathrm{Zr}$ which, in turn, enhances the hydrogen spillover effect. The increased dispersion of the $\alpha-\mathrm{Fe}_{2} \mathrm{O}_{3}$ and $\mathrm{ZnFe}_{2} \mathrm{O}_{4}$ phases enhances the hydrogen spillover effect, leading to increased reduction and nucleation of the surface oxides. The promotion effect is further amplified when $\mathrm{Fe}-\mathrm{Zn}-\mathrm{Zr}$ is co-promoted with $\mathrm{Cu}$ and $\mathrm{Ca}$. This unprecedented hydrogen consumption in $\mathrm{Fe}-\mathrm{Zn}-\mathrm{Zr}-\mathrm{Cu}-\mathrm{Ca}$ may be explained as being due to the combined dispersion effect of $\mathrm{Zr}$ and $\mathrm{Ca}$ and the enhanced hydrogen spillover effect of $\mathrm{Cu}$. The presence of $\mathrm{Zr}$ and $\mathrm{Ca}$ produces dramatic dispersion of the $\alpha-\mathrm{Fe}_{2} \mathrm{O}_{3}$ and $\mathrm{ZnFe}_{2} \mathrm{O}_{4}$ phases, leading to their facile reduction in the presence of $\mathrm{Cu}$. Such synergistic effects of promoters for enhancing the dispersion of active components have not been reported before for iron-based FT catalysts.

\subsection{Carburisation Behaviour}

Figure 5 shows the CO-TPR profiles of the catalysts. The CO-TPR profiles provide information about the carburisation behaviour of the catalysts. The peaks in the CO-TPR profiles are not well resolved, as is the case for the $\mathrm{H}_{2}$-TPR profiles. This is because reduction and carburisation occur concurrently during the temperature programme under the flow of $\mathrm{CO}$ gas, whereas the $\mathrm{H}_{2}$-TPR process is void of this complication. This translates into a challenge in the

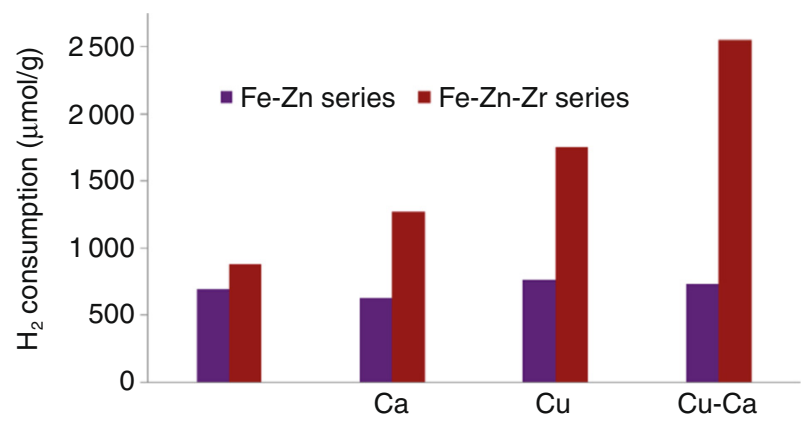

Figure 4

$\mathrm{H}_{2}$ consumption for $\mathrm{Fe}_{2} \mathrm{O}_{3} \rightarrow \mathrm{Fe}_{3} \mathrm{O}_{4}$ transitions in the catalysts.

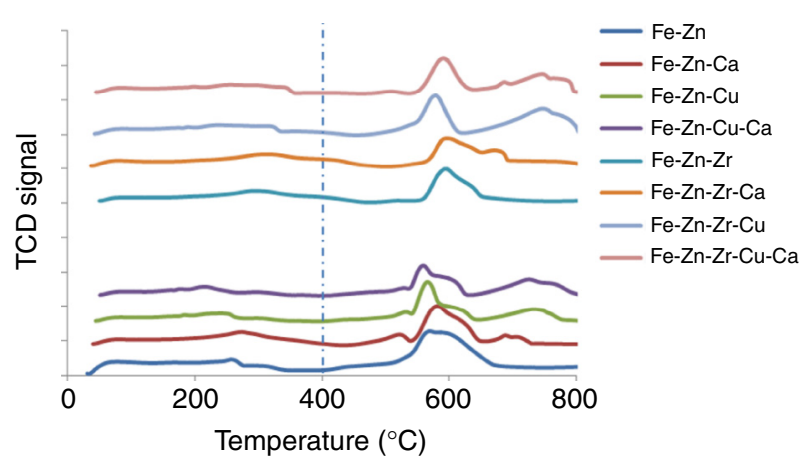

Figure 5

CO-TPR profiles of the catalysts. 
interpretation of CO-TPR profiles obtained by a TCD signal. A close examination of Figure 6 shows that the catalysts display similar CO-TPR profile patterns. These are made up of small, broad low temperature peaks below $400^{\circ} \mathrm{C}$ and larger peaks with shoulders above $400^{\circ} \mathrm{C}$. According to $\mathrm{Li}$ et al. [11], $\mathrm{Fe}_{2} \mathrm{O}_{3}$ reduces to $\mathrm{Fe}_{3} \mathrm{O}_{4}$ in $\mathrm{CO}$ at $270^{\circ} \mathrm{C}$ and subsequent carburisation of $\mathrm{Fe}_{3} \mathrm{O}_{4}$ occurs above a temperature of $270^{\circ} \mathrm{C}$. However, at temperatures above $400^{\circ} \mathrm{C}$, carburisation is accompanied by excessive formation of amorphous carbon due to disproportionation of $\mathrm{CO}$ (Boudouard reaction). This implies that the peaks at temperatures above $400^{\circ} \mathrm{C}$ are of little or no relevance in determining catalyst behaviour in actual FT conditions. Thus, further discussion on the CO-TPR profile of the catalysts will be limited to the peaks below $400^{\circ} \mathrm{C}$. Since carburisation of the iron oxide phase proceeds without first having been reduced to the metallic state and peak assignment is rather difficult, we looked at $\mathrm{CO}$ consumption to estimate the extent of carburisation of the catalysts at temperatures below $400^{\circ} \mathrm{C}$. We adopted the reaction:

$$
\mathrm{Fe}_{2} \mathrm{O}_{3}+\frac{1}{3} \mathrm{CO} \rightarrow \frac{2}{3} \mathrm{Fe}_{3} \mathrm{O}_{4}+\frac{1}{3} \mathrm{CO}_{2}
$$

as a reference, and the amounts of $\mathrm{CO}$ required for this reaction for $\mathrm{Fe}-\mathrm{Zn}$ and $\mathrm{Fe}-\mathrm{Zn}$ - Zr series are 2783 and $2656 \mu \mathrm{mol} \mathrm{g}^{-1}$, respectively. CO consumption in excess of the reference amount is taken as $\mathrm{CO}$ consumption for carburisation. The $\mathrm{CO}$ consumption of the catalysts is presented in Figure 6, which shows that $\mathrm{CO}$ consumption in all the catalysts is above the reference amount. This reiterates that the $\mathrm{Fe}_{2} \mathrm{O}_{3} \rightarrow \mathrm{Fe}_{3} \mathrm{O}_{4}$ is facile below $400^{\circ} \mathrm{C}$ and carburisation of the catalyst can be carried out.
Ca promotion of Fe- $\mathrm{Zn}$ does not significantly affect $\mathrm{CO}$ consumption but addition of $\mathrm{Cu}$ to $\mathrm{Fe}-\mathrm{Zn}$ decreases the $\mathrm{CO}$ consumption, indicating that $\mathrm{Cu}$ promotion leads to resistance to carburisation.

The Fe- Zn-Zr catalyst series display higher CO consumption than their Fe-Zn counterparts. This may be attributed to the higher amount of $\alpha-\mathrm{Fe}_{2} \mathrm{O}_{3}$ and the textural promotion effect of $\mathrm{Zr}$ in the $\mathrm{Fe}-\mathrm{Zn}-\mathrm{Zr}$ catalyst series. Addition of $\mathrm{Ca}$ to $\mathrm{Fe}-\mathrm{Zn}-\mathrm{Zr}$ produces a dramatic increase in $\mathrm{CO}$ consumption; this is most probably due to increased dispersion of the $\alpha-\mathrm{Fe}_{2} \mathrm{O}_{3}$ and $\mathrm{ZnFe}_{2} \mathrm{O}_{4}$ phases. However, $\mathrm{Cu}$ promotion of $\mathrm{Fe}-\mathrm{Zn}-\mathrm{Zr}$ did not significantly affect the carburisation. Here, carburisation resistance of $\mathrm{Cu}$ is masked by the presence of $\mathrm{Zr}$ on the catalysts. The $\mathrm{Cu}$ particles are preferentially distributed close to $\mathrm{Zr}$. This preferential distribution of $\mathrm{Cu}$ particles seems relapsed when co-promoted with $\mathrm{Ca}$, and the carburisation resistance effect of $\mathrm{Cu}$ re-emerges to account for the lower $\mathrm{CO}$ consumption in $\mathrm{Fe}-\mathrm{Zn}-\mathrm{Zr}-\mathrm{Cu}-\mathrm{Ca}$ compared with $\mathrm{Fe}-\mathrm{Zn}-\mathrm{Zr}-\mathrm{Cu}$ and $\mathrm{Fe}-\mathrm{Zn}-\mathrm{Zr}$. This carburisation behaviour of the catalysts is expected to impact on their performance for FT operations. FT evaluations of the catalysts are ongoing in our laboratory.

\subsection{Surface Acidity}

Catalyst surface acidity impacts on FT production distribution. High surface acidity promotes acid-catalysed secondary reactions (such as cracking, isomerisation and aromatisation) of primary FT products. It can also aid rapid deactivation of the catalysts due to coke formation. The $\mathrm{NH}_{3}$-TPD profiles presented in Figure 7 give information on the surface acidity of the two catalysts' series. For simpler quantitative interpretations, the profiles are partitioned into two temperature ranges to rank

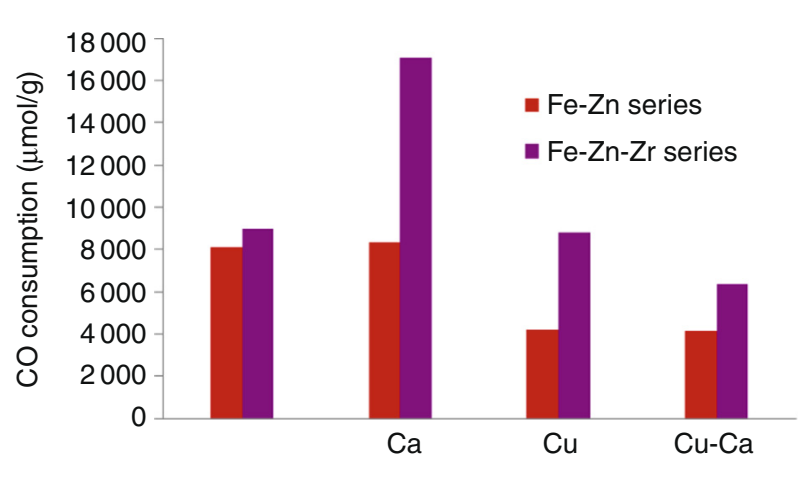

Figure 6

CO consumption measured by area under the peak in different temperature ranges in the CO-TPR profiles of the catalysts.

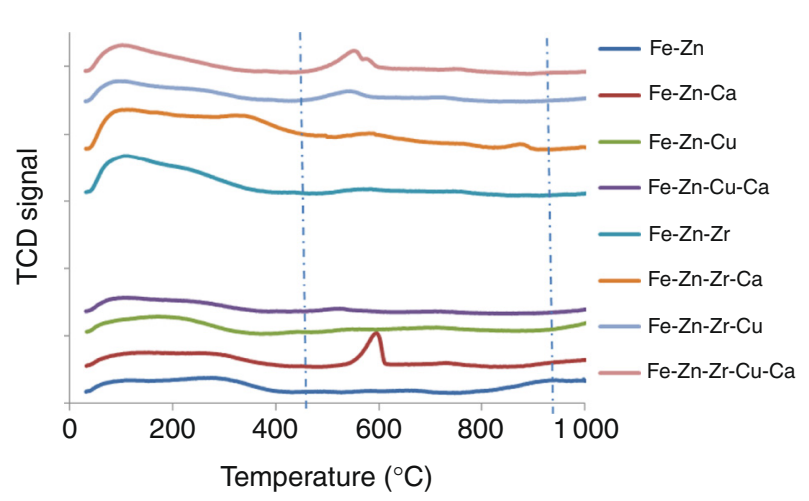

Figure 7

$\mathrm{NH}_{3}$-TPD profiles of the catalysts. 
the surface acid strength in increasing order of the peak temperatures.

The distributions of the surface acid sites of the catalysts are presented in Figure 8. As can be seen from Figure 7, a sharp peak of strong sites emerges on the profile of the $\mathrm{Fe}-\mathrm{Zn}-\mathrm{Ca}$ catalyst (a similar peak is present in the $\mathrm{CO}_{2}$-TPD profile of the catalyst). A peak connoting the strong acidic site of this nature is quite unexpected for an alkaline cation promotion. The possible phases of $\mathrm{Ca}$ in the catalysts are $\mathrm{CaO}, \mathrm{Ca}(\mathrm{OH})_{2}$ or $\mathrm{CaCO}_{3}$. Ordinarily, precipitation of calcium nitrate with sodium carbonate will produce calcium carbonate and decomposition of $\mathrm{CaCO}_{3}$ normally takes place at $>800^{\circ} \mathrm{C}$, but the peak temperature $\left(580^{\circ} \mathrm{C}\right)$ corresponds with the temperature of the reaction [20]:

$$
\mathrm{Ca}(\mathrm{OH})_{2(\mathrm{~s})} \rightarrow \mathrm{CaO}_{(\mathrm{s})}+\mathrm{H}_{2} \mathrm{O}_{(\mathrm{g})}
$$

It thus suggests that $\mathrm{Ca}$ is present as the $\mathrm{Ca}(\mathrm{OH})_{2}$ phase in the Fe-Zn-Ca catalyst. Another plausible explanation is that $\mathrm{Ca}^{2+}$ is incorporated into the lattice of $\alpha-\mathrm{Fe}_{2} \mathrm{O}_{3}$ or $\mathrm{ZnFe}_{2} \mathrm{O}_{4}$ with strongly bonded hydroxide ions. $\mathrm{Cu}$ promotion decreases the acid site densities of $\mathrm{Fe}-\mathrm{Zn}$. It appears that $\mathrm{Cu}$ titrates the weak acid sites.

Addition of $\mathrm{Zr}$ to Fe-Zn brings about site redistribution in favour of weaker acidic sites. Here, Cu promotion of Fe- $\mathrm{Zn}-\mathrm{Zr}$ leads to an increased proportion of strong acid sites and a slight increase in the total acid sites' density. However, the presence of $\mathrm{Ca}$ in $\mathrm{Fe}-\mathrm{Zn}-\mathrm{Zr}$ brings about almost double the density of the acidic sites. This situation is most probably due to the dispersion effect of $\mathrm{Zr}$ discussed earlier and its enhancement when jointly added with $\mathrm{Ca}$ to the $\alpha-\mathrm{Fe}_{2} \mathrm{O}_{3}$ and $\mathrm{ZnFe}_{2} \mathrm{O}_{4}$ phases. It appears that addition of $\mathrm{Ca}$ to $\mathrm{Fe}-\mathrm{Zn}-\mathrm{Zr}-\mathrm{Cu}$ produces a similar effect to that observed when $\mathrm{Fe}-\mathrm{Zn}$ is promoted with $\mathrm{Ca}$. When compared with $\mathrm{Fe}-\mathrm{Zn}-\mathrm{Zr}-\mathrm{Cu}$, strong acid sites seem to increase in $\mathrm{Fe}-\mathrm{Zn}-\mathrm{Zr}-\mathrm{Cu}-\mathrm{Ca}$ at the expense of weak-strength sites. The acid site distribution suggests that there is a greater tendency for an acid catalysed secondary reaction in the Fe-Zn-Zr than in the Fe- Zn series, while $\mathrm{Cu}$ and $\mathrm{Ca}$ promotion suppresses surface acidity in $\mathrm{Fe}-\mathrm{Zn}$ and is again reinforced in $\mathrm{Fe}-\mathrm{Zn}-\mathrm{Zr}$.

\subsection{Surface Basicity}

The $\mathrm{CO}_{2}$-TPD profiles of the catalysts are shown in Figure 9. The profile is partitioned into two regions as in the $\mathrm{NH}_{3}$-TPD profiles, and the densities of the basic sites of the catalysts are presented in Figure 10. The sharp peak at $580^{\circ} \mathrm{C}$ observed in the $\mathrm{NH}_{3}$-TPD profile of $\mathrm{Fe}-\mathrm{Zn}-\mathrm{Ca}$ is also present in its $\mathrm{CO}_{2}$-TPD profile. The implication of this peak has been discussed in Section 2.3. $\mathrm{Cu}$ promotion of $\mathrm{Fe}-\mathrm{Zn}$ slightly increases the proportion of strong basic sites. The basicity of $\mathrm{Ca}$ and $\mathrm{Cu}$ promotion appears to cancel out in the $\mathrm{Cu}-\mathrm{Ca}$ promoted catalyst [21]. The presence of $\mathrm{Zr}$ in Fe- $\mathrm{Zn}$ does not significantly affect its surface basicity. However, $\mathrm{Cu}$ and $\mathrm{Ca}$ promotion in the $\mathrm{Fe}-\mathrm{Zn}-\mathrm{Zr}$ series displays a different trend compared with the $\mathrm{Fe}-\mathrm{Zn}$ series. Creation of strong basic sites is obtained in the $\mathrm{Cu}$-promoted catalyst. Here, Ca promotion imparts formation of strong basic sites and total basic site density is markedly increased. The cancelling-out effect of $\mathrm{Cu}-\mathrm{Ca}$ co-promotion is also observed in the Fe-Zn-Zr-Cu-Ca catalyst.

Like acidic sites, basic sites can also influence FT product distribution. In our recent review report [10], we commented that the effect of basic sites impacting promoters on FT product selectivity, especially its potential toward producing non-ASF product distribution, has not been rigorously investigated, as is the case for acidic sites. As mentioned before, $\mathrm{Cu}$ and $\mathrm{K}$ are benchmark promoters in commercial iron $\left(\mathrm{Fe}-\mathrm{SiO}_{2}\right)$ -

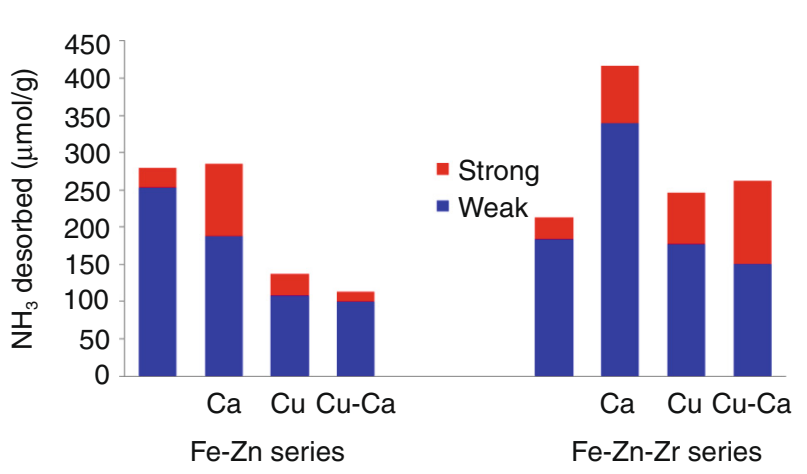

Figure 8

Amount of $\mathrm{NH}_{3}$ desorbed measured by area under the peak in different temperature ranges in the $\mathrm{NH}_{3}$-TPD profiles of the catalysts.

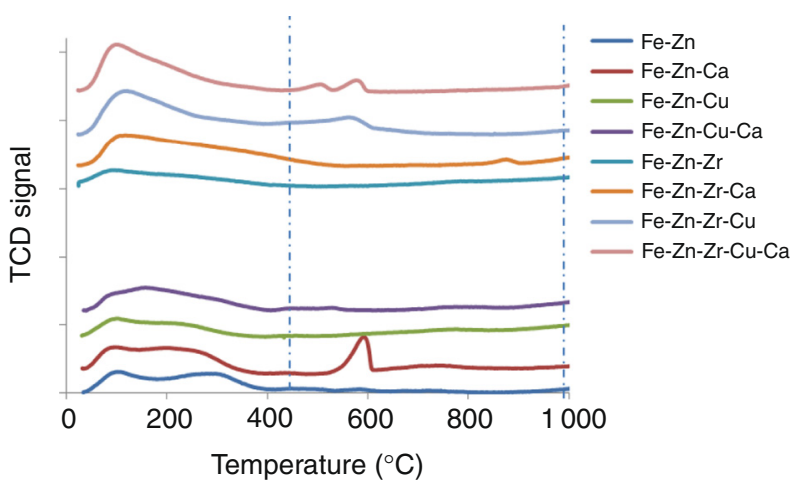

Figure 9

$\mathrm{CO}_{2}$-TPD profiles of the catalysts. 


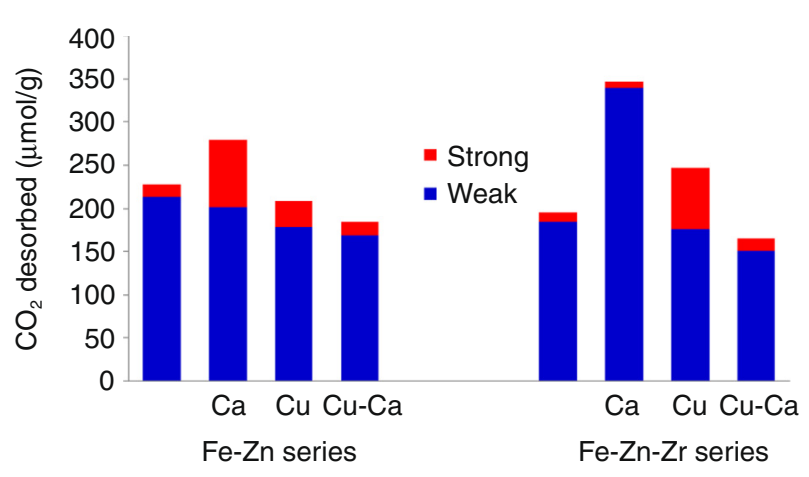

Figure 10

Amount of $\mathrm{CO}_{2}$ desorbed measured by area under the peak in different temperature ranges in the $\mathrm{CO}_{2}$-TPD profiles of the catalysts.

based FT catalysts, and most studies on effects of basic sites in FTS have focused on $\mathrm{K}$. The $\mathrm{K}$ promoter is usually added to catalysts via impregnation with $\mathrm{K}_{2} \mathrm{CO}_{3}$ solution followed by calcination at $400-500^{\circ} \mathrm{C}$. The impregnated $\mathrm{K}$ can present as the $\mathrm{K}_{2} \mathrm{CO}_{3}$, silicate phase or form a compound/complex with $\mathrm{Fe}$ oxides and/or silica. In all these phases, the impregnated $\mathrm{K}$ is prone to leaching out of the catalyst in the course of the FT reaction. Hence, the supposed basic sites imparted on the catalyst due to the presence of $\mathrm{K}$ may be short-lived and the product distributions obtained may lack the sustained influence of basic sites.

Carbonates, hydroxides and oxides of Group II metals are less susceptible to leaching under FT reaction conditions. They are better candidates for examining the effect of basic sites in FT product selectivity. However, there are very few investigations on this aspect where the Group II cations (nitrate salts) are added to $\mathrm{Fe}_{-} \mathrm{SiO}_{2}$-based catalysts via impregnation [22-24] followed by calcination at $350-450^{\circ} \mathrm{C}$ for $4 \mathrm{~h}$. There is a tendency for $\mathrm{Ca}$ to remain in the nitrate phase since $\mathrm{Ca}\left(\mathrm{NO}_{3}\right)_{2}$ decomposes at temperatures above $550^{\circ} \mathrm{C}$ even in a reducing atmosphere [25-26]. In this phase, $\mathrm{Ca}$ is susceptible to leaching, as described for Tao et al. [27] who introduced $\mathrm{Ca}$ into $\mathrm{Fe}-\mathrm{Mn}$ oxide by co-precipitation. Here, the challenge of $\mathrm{Ca}\left(\mathrm{NO}_{3}\right)_{2}$ decomposition is absent. It also has the advantage of being a one-step method (co-precipitation) instead of a two-step method (co-precipitation followed by impregnation) using K. However, in their study, the authors further added $\mathrm{K}$ to the catalyst. This makes it difficult to delineate the promotion effect of $\mathrm{Ca}$ from that of $\mathrm{K}$ in their catalyst and make a direct comparison with the present study.

\section{CONCLUSIONS}

We explored $\mathrm{Zr}$ as a promoter for boosting the active sites in Fe-Zn-based catalysts towards developing iron catalysts that can match cobalt-based catalysts in FT activity. For this purpose, we used TPR $\left(\mathrm{H}_{2}\right.$ and $\left.\mathrm{CO}\right)$ and TPD $\left(\mathrm{NH}_{3}\right.$ and $\left.\mathrm{CO}_{2}\right)$ to gain insights into FTS active site precursors, hydrogenation tendency and surface acidity/basicity of the catalysts. The results are presented as a comparative study of the effect of $\mathrm{Cu}$ and $\mathrm{Ca}$ promotion on reduction and carburisation behaviour and surface acidity/basicity of Fe-Zn and Fe-Zn-Zr catalysts. The presence of $\mathrm{Zr}$ improved dispersion of the FTS active sites of precursors. Further, $\mathrm{Cu}$ and $\mathrm{Ca}$ synergistically increased the amount of the FTS active sites of precursors in Fe-Zn-Zr-Cu-Ca-based catalysts. The presence of $\mathrm{Ca}$ promotes carburisation but $\mathrm{Cu}$ inhibits carburisation. The impact of the $\mathrm{Ca}$ and $\mathrm{Cu}$ on the surface acidity/basicity is governed by the nature of the interaction between the phases in the catalysts. The extent of reduction reflects the availability and dispersion of the precursor to the active face, while the extent of carburisation will impact on the selectivity of the catalysts. The results from this study suggest that Fe-Zn-Zr$\mathrm{Cu}-\mathrm{Ca}$ may compare fairly well with a cobalt catalyst in terms of activity (per gram catalyst) and $\mathrm{CO}_{2}$ selectivity. When this is confirmed by LTFT tests, the next goal will be to improve the stability of the catalyst.

\section{ACKNOWLEDGMENTS}

S.M. and James thank Director, Central Institute of Mining and Fuel Research for permitting to publish this report; and James is grateful to TWAS (Trieste, Italy) and CSIR (India) for the award of a TWAS-CSIR Postgraduate Fellowship.

\section{REFERENCES}

1 Owen N.A., Inderwildi O.R., King D.A. (2010) The status of conventional world oil reserves-Hype or cause for concern?, Energy Policy 38, 8, 4743-4749.

2 Sorrell S., Speirs J., Bentley R., Brandt A., Miller R. (2010) Global oil depletion: A review of the evidence, Energy Policy 38, 9, 5290-5295.

3 Casci J.L., Lok C.M., Shannon M.D. (2009) FischerTropsch catalysis: The basis for an emerging industry with origins in the early 20th Century, Catal. Today 145, 1-2, $38-44$.

4 James O.O., Mesubi A.M., Ako T.C., Maity S. (2010) Increasing carbon utilization in Fischer-Tropsch synthesis using $\mathrm{H}_{2}$-deficient or $\mathrm{CO}_{2}$-rich syngas feeds, Fuel Process. Technol. 91, 2, 136-144. 
5 Buzcu-Guven B., Harriss R. (2012) Extent, impacts and remedies of global gas flaring and venting, Carbon Manage. 3, 1, 95-108.

6 Buping B., El-Halwagi M.M., Elbashir N.O. (2010) Simulation, integration, and economic analysis of gas-to-liquid processes, Fuel Process. Technol. 91, 7, 703-713.

7 Zhang Q., Kang J., Wang Y. (2010) Development of Novel Catalysts for Fischer-Tropsch Synthesis: Tuning the Product Selectivity, ChemCatChem 2, 9, 1030-1058.

8 Davis B.H. (2007) Fischer-Tropsch Synthesis: Comparison of Performances of Iron and Cobalt Catalysts, Ind. Eng. Chem. Res. 46, 26, 8938-8945.

9 de Klerk A. (2009) Can Fischer-Tropsch Syncrude Be Refined to On-Specification Diesel Fuel?, Energy Fuels 23, 9, 4593-4604.

10 James O.O., Chowdhury B., Mesubi A.M., Maity S. (2012) Reflections on Chemistry of Fischer-Tropsch Synthesis, RSC Advances 2, 7347-7366.

11 Li S., Krishnamoorthy S., Li A., Meitzner G.D., Iglesia E. (2002) Promoted Iron-Based Catalysts for the FischerTropsch Synthesis: Design, Synthesis, Site Densities, and Catalytic Properties, J. Catal. 206, 2, 202-217.

12 Fujiwara M., Kieffer R., Ando H., Xu Q., Souma Y. (1997) Change of catalytic properties of $\mathrm{Fe}-\mathrm{ZnO}$ /zeolite composite catalyst in the hydrogenation of carbon dioxide, Appl. Catal. A: Gen. 154, 1, 87-101.

13 Bai Rongxian, Tan Yisheng, Han Yizhuo (2004) Study on the carbon dioxide hydrogenation to iso-alkanes over $\mathrm{Fe}-\mathrm{Zn}-\mathrm{M} /$ zeolite composite catalysts, Fuel Process. Technol. 86, 3, 293-301.

14 Ni X., Tan Y., Han Y., Tsubaki N. (2007) Synthesis of isoalkanes over $\mathrm{Fe}-\mathrm{Zn}-\mathrm{Zr} / \mathrm{HY}$ composite catalyst through carbon dioxide hydrogenation, Catal. Commun. 8, 17111714.

15 Li S., Li A., Krishnamoorthy S., Iglesia E. (2001) Effects of $\mathrm{Zn}, \mathrm{Cu}$, and $\mathrm{K}$ Promoters on the Structuure and on Reaction and Carburization, and Catalytic Behavior of IornBased Fischer-Tropsch Synthesis Catalysts, Catal. Lett. 77, 4, 197-205.

16 Lohitharn N., Goodwin Jr. J.G., Lotero E. (2008) Fe-based Fischer-Tropsch synthesis catalysts containing carbideforming transition metal promoters, J. Catal. 255, 1, 104113 .

17 Lohitharn N., Goodwin Jr. J.G. (2008) Impact of Cr, Mn and $\mathrm{Zr}$ addition on Fe Fischer-Tropsch synthesis catalysis: Investigation at the active site level using SSITKA, $J$. Catal. 257, 1, 142-151.
18 Ojeda M., Nabar R., Nilekar A.U., Ishikawa A., Mavrikakis M., Iglesia E. (2010) CO activation pathways and the mechanism of Fischer-Tropsch synthesis, J. Catal. 272, 287-297.

19 Stephan D.W. (2008) "Frustrated Lewis pairs": a concept for new reactivity and catalysis, Org. Biomol. Chem. 6, 1535-1539.

20 Kanzawa A., Arai Y. (1981) Thermal energy storage by the chemical reaction augmentation of heat transfer and thermal decomposition in the $\mathrm{CaO} / \mathrm{Ca}(\mathrm{OH})_{2}$ powder, Sol. Energy 27, 4, 289-294.

21 Alfonso D.R., Jaffe J.E., Hess A.C., Gutowski M. (2003) Formation of the $c(1 \times 1) \mathrm{Cu}$ monolayer on $\mathrm{CaO}(100)$ : A theoretical study, Phys. Rev. B 68, 155411.

22 Luo M., Davis B.H. (2003) Fischer-Tropsch synthesis: Group II alkali-earth metal promoted catalysts, Appl. Catal. A: Gen. 246, 171-181.

23 Nakhaei Pour A., Housaindokht M.R., Tayyari S.F., Zarkesh J., Alaei M.R. (2010) Kinetic studies of the Fischer-Tropsch synthesis over $\mathrm{La}, \mathrm{Mg}$ and $\mathrm{Ca}$ promoted nano-structured iron catalyst, J. Nat. Gas Sci. Eng. 2, 61-68.

24 Nakhaei Pour A., Kamali Shahri S.M., Reza Bozorgzadeh H., Zamani Y., Tavasoli A., Ahmadi Marvast M. (2008) Effect of $\mathrm{Mg}, \mathrm{La}$ and $\mathrm{Ca}$ promoters on the structure and catalytic behavior of iron-based catalysts in Fischer-Tropsch synthesis, Appl. Catal. A: Gen. 348, 2, 201-208.

25 Shanmugam Yuvaraj, Lin Fan-Yuan, Chang Tsong-Huei, Yeh Chuin-Tih (2003) Thermal Decomposition of Metal Nitrates in Air and Hydrogen Environments, J. Phys. Chem. B 107, 1044-1047.

26 Brockner W., Ehrhardt C., Gjikaj M. (2007) Thermal decomposition of nickel nitrate hexahydrate, $\mathrm{Ni}$ $\left(\mathrm{NO}_{3}\right)_{2} \cdot 6 \mathrm{H}_{2} \mathrm{O}$, in comparison to $\mathrm{Co}\left(\mathrm{NO}_{3}\right)_{2} \cdot 6 \mathrm{H}_{2} \mathrm{O}$ and $\mathrm{Ca}$ $\left(\mathrm{NO}_{3}\right)_{2} \cdot 4 \mathrm{H}_{2} \mathrm{O}$, Thermochimica Acta 456, 64-68.

27 Tao Zhichao, Yang Yong, Zhang Chenghua, Li Tingzhen, Wang Jianhua, Wan Haijun, Xiang Hongwei, Li Yongwang (2006) Effect of calcium promoter on a precipitated iron-manganese catalyst for Fischer-Tropsch synthesis, Catal. Commun. 7, 1061-1066.

Manuscript accepted in February 2013 Published online in December 2013

Cite this article as: O. O. James, B. Chowdhury and S. Maity (2015). Comparative TPR and TPD Studies of Cu and Ca Promotion on Fe-Zn- and Fe-Zn-Zr-Based Fischer-Tropsch Catalysts, Oil Gas Sci. Technol 70, 3, 511-519. 